\title{
Anuran diversity of four taxocenoses of the subtropical Atlantic Forest from Santa Catarina and Paraná states Brazil
}

\author{
Lucas Ribeiro Mariotto ${ }^{1}$ \\ 1 Universidade de São Paulo (USP), Faculdade de Filosofia, Ciências e Letras de Ribeirão Preto (FFCLRP), \\ Departamento de Biologia (DB), Programa de Pós-Graduação em Biologia Comparada. Ribeirão Preto, SP, Brasil. \\ ORCID: http://orcid.org/0000-0002-9397-4001. E-mail: lucasrmariotto@gmail.com
}

\begin{abstract}
Local fauna inventories provide primary key information on diversity and distribution of species for conservation purposes. The Atlantic Forest holds 50\% of anuran species in the country and the main threats to the conservation of this fauna are habitat reduction and fragmentation. The present study brings information on the local richness and species composition of four anuran taxocenoses from the subtropical Atlantic Forest of Paraná and Santa Catarina states, Brazil. Data collection included breeding sites surveys $(\mathrm{N}=56)$ and literature review. Richness and beta diversity were compared through rarefaction/ extrapolation curves, local contribution to beta diversity (LCBD), beta partitioning and cluster analysis. Anuran from 46 species were registered and local richness differences were observed on the rarefaction/extrapolation curves and on asymptotic analysis. Nevertheless, the LCBD did not detect differences in species composition among the four taxocenoses. The turnover was the predominant component of beta diversity. The geographical distances explain species composition for all localities compiled in this study. The differences among local richness may be related to environmental impacts, emphasizing the need for conservation of biodiversity in the remnants of Atlantic forest.
\end{abstract}

Key-Words. Species richness; Species composition; Inventory; Atlantic Forest; Conservation.

\section{INTRODUCTION}

Brazil withholds one of the highest diversity of anurans in the world (Segalla et al., 2019), whereas 530 species are found in the Atlantic Forest and $85 \%$ of these species are endemic of this biome (Haddad \& Prado, 2005; Haddad et al., 2013). The original forest covered 150 million hectares of the Brazilian northeast coast to the south of the country, going as far as Paraguay and Argentina with formations of Interior and Araucaria Forests. Nowadays, only $11.73 \%$ of the original forest remains, in a fragmented landscape formed in its majority by small fragments $(<50$ hectares) (Ribeiro et al., 2009), making it one of the 25 hotspots for the conservation of world-wide biodiversity (Myers et al., 2000). Anuran diversity suffers a negative impact with the fragmentation of habitats (Silvano et al., 2003). Habitats that are better preserved possess greater environmental heterogeneity and high number of micro environments improves the coexistence of species (Sazima \& Eterovick, 2000; Vasconcelos et al., 2009; Silva et al., 2012a, b). Therefore, the diminishing habitat quality, fragmentation, homogenization and loss of habitats are considered the main causes of the decline of anuran populations and biodiversity loss in Brazil and in the world (Young et al., 2001; Cushman, 2006; ICMBio, 2018; IUCN, 2020).

Southern Brazil is mostly included in the subtropical Atlantic Forest which is divided by sub-regions, wherein a valuable diversity of anurans still resides: Atlantic Coast Restingas of Brazil - 79 species, seven exclusive species (Garcia et al., 2007); Araucaria Forest 129 species, 13 being endemic (Conte, 2010); Serra do Mar 165 species, being 38 endemic (Garcia et al., 2007); and the Interior Forests 111 species, being only five endemic (Garcia et al., 2007).

Environmental studies that perform local inventories and use parameters of richness and species composition to describe taxocenoses allow us to access information on biodiversity, as well as to carry through a diagnosis on the conservation status and conduct actions of biodiversity preservation (Verdade et al., 2012). Therefore, this work aims to make an anuran inventory of four areas of the subtropical Atlantic Forest and to compare them, through local richness and species composition parameters, with other anuran taxocenoses from southern Brazil. 


\section{MATERIAL AND METHODS}

\section{Study Areas}

The states of Rio Grande do Sul, Santa Catarina and Paraná are mostly located in the subtropical region, in the Atlantic Tropical Morphoclimatic Domain and in the Araucaria Plateau (Ab'Saber, 1977) (Fig. 1). Four areas in the eastern region of Santa Catarina and Paraná states, Brazil (Fig. 2) were sampled for this study. The first area (BR-470), which included phytophysiognomies of the Lowland Dense Ombrophilous Forest (Veloso et al., 2012), was sampled along the BR-470 highway, between the municipalities of Ilhota and Indaial, Santa Catarina state. The second studied location (MGAN) included Sub-montane Dense Ombrophilous Forest (Veloso et al., 2012) lying between the municipalities of Major Gercino and Angelina, in the state of Santa Catarina, close to a small hydropow- er plant reservoir. The third area (SC-370) included the Mixed Ombrophilous Forest's phytophysignomy (Veloso et al., 2012) along the SC-370 highway located in Urubici municipality, Santa Catarina state. Finally, the fourth area (BR-116) included the Mixed Ombrophilous Forest phytophysignomy (Veloso et al., 2012), sampled along BR-116 highway, between the municipalities of Curitiba and Mandirituba, Paraná state. The search for frogs was conducted in several breeding sites (streams, permanent ponds and temporary swamps) found in open areas and forest fragments (Fig. 2, see Appendix 1).

\section{Sampling}

The fieldworks were conducted from 2010 to 2013: the BR-470 was sampled in 2010, SC-370 and MGAN in 2010-2011 and BR-116 in 2012-2013, constituting one

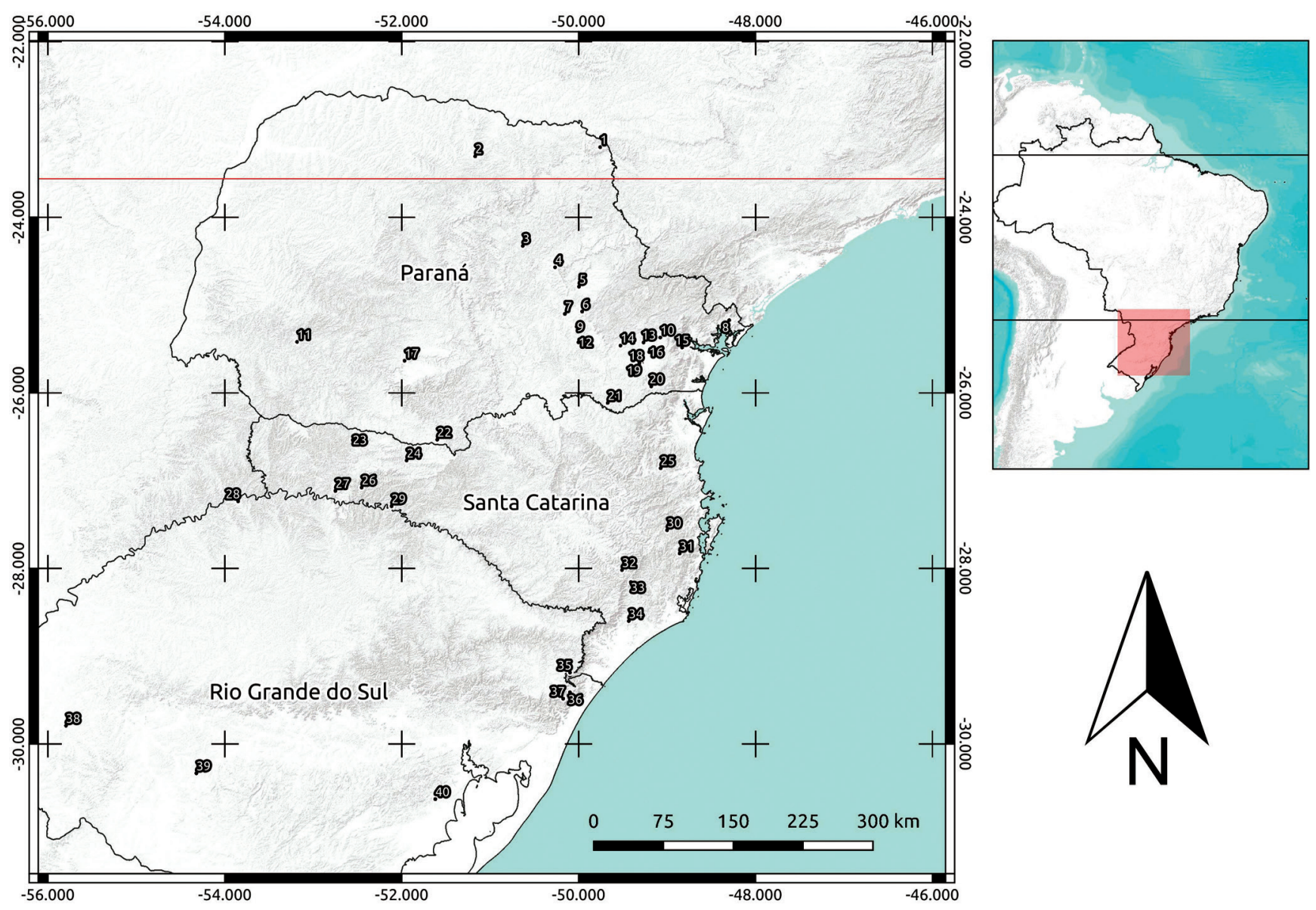

Figure 1. Map showing collection points in the four localities studied: BR-470 highway between Ilhota and Indaial municipalities (point 25), Santa Catarina state; Angelina and Major Gercino municipalities (point 30), Santa Catarina state; SC-370 highway in Urubici municipality (point 32), Santa Catarina state; and BR-116 highway between Curitiba and Mandirituba municipalities (point 19), Paraná state; and the other localities from literature: (1) Ribeirão Claro municipality, Paraná state, (2) low Tibagi river, (3) medium Tibagi river, (4) Parque Estadual do Guartelá, (5) Parque Estadual do Caxambú, (6) Parque Nacional dos Campos Gerais, (7) upper Tibagi river, (8) Reserva Natural Salto Morato, (9) Parque Estadual de Vila Velha, (10) Quatro Barras municipality, Paraná state, (11) Parque Estadual do Rio Guarani, (12) Palmeira municipality, Paraná state, (13) Curitiba municipality, Paraná state, (14) Campo Largo municipality, Paraná state, (15) Morretes municipality, Paraná state, (16) São José dos Pinhas municipality, Paraná state, (17) Parque Estadual Santa Clara, (18) Fazenda Experimental Gralha-Azul, (20) Tijucas do Sul municipality, Paraná state, (21) Rio Negro municipality, Paraná state, (22) Reserva da Vida Silvestre de Palmas, (23) UHE Quebra-Queixo, (24) Parque Nacional das Araucárias, (26) Irani river, (27) Floresta Nacional de Chapecó, (28) Parque Estadual do Turvo, (29) Parque Estadual Fritz Plaumann, (31) Parque Estadual da Serra do Tabuleiro, (33) Parque Estadual da Serra Furada, (34) Siderópolis municipality, Santa Catarina state, (35) Parque Nacional dos Aparados da Serra, (36) Parque Estadual de Itapeva, (37) Gaúcha mountain range, (38) Área de Proteção Ambiental Ibirapuitã, (39) Fundação Estadual de Pesquisa Agropecuária (FEPA), (40) Sentinela do Sul municipality, Rio Grande do Sul state. Red line - Capricorn tropic. 


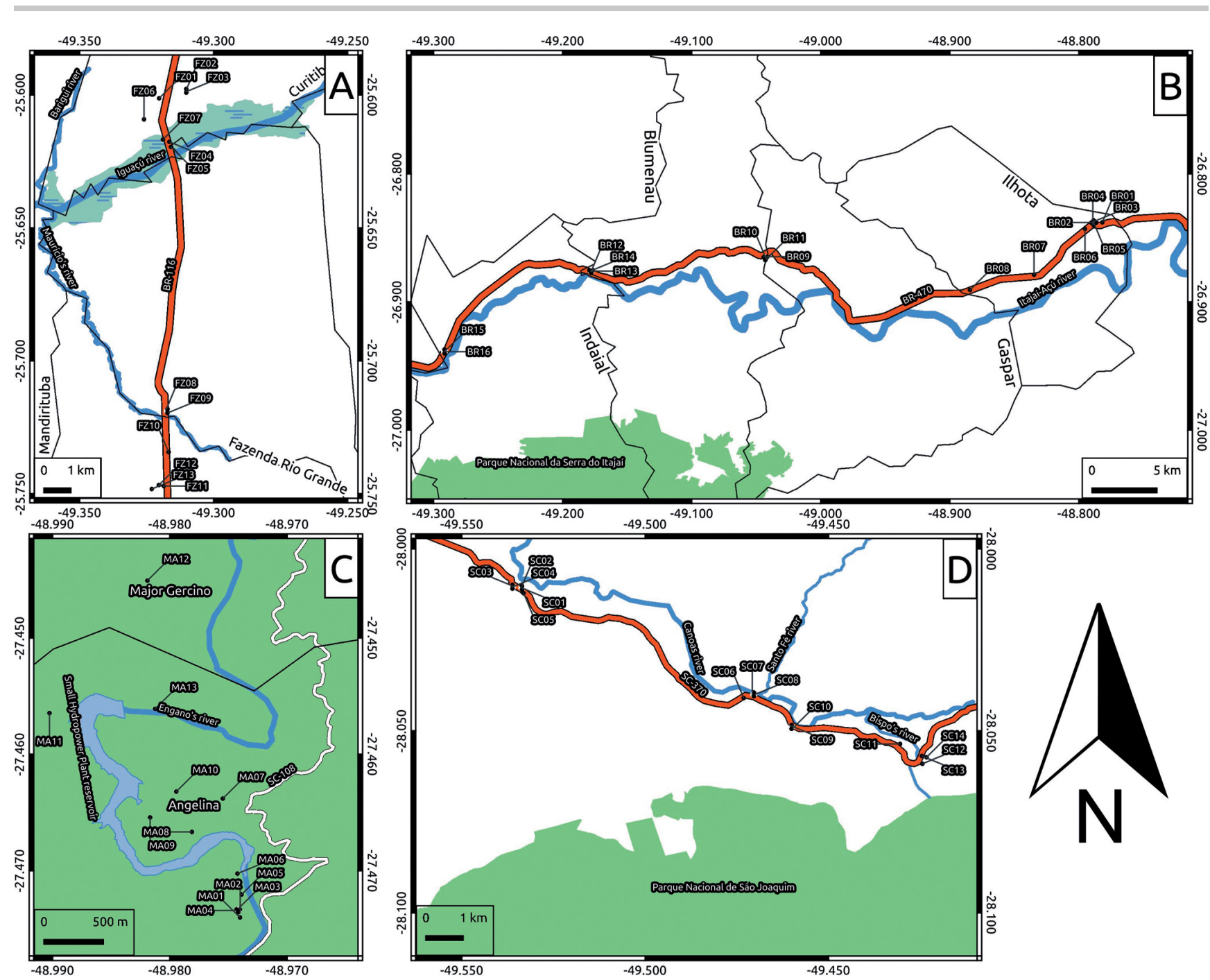

Figure 2. Map showing collection of breeding sites in the four localities studied: (A) BR-116 highway between Curitiba and Mandirituba municipalities (BR-116 $-n=13$ ), Paraná state; (B) BR-470 highway between Ilhota and Indaial municipalities (BR-470 - $n=16$ ), Santa Catarina state; (C) Angelina and Major Gercino municipalities (MGAN - n=13), Santa Catarina state; (D) SC-370 highway in Urubici municipality (SC-370 $-n=14$ ), Santa Catarina state.

campaign of five days per trimesters and an effort of about 20 hours of search for each campaign. The samples occurred within the four seasons in each area, except for the winter campaign in SC-370 which was not held. The BR-116 was sampled twice during each season (see Appendix 2).

The Visual Encounters and Surveys at Bredding Sites were used as the standard sampling methods (Crump \& Scott Jr., 1994; Scott Jr. \& Woodward, 1994). The richness and abundance of species were registered for each breeding site sampled in each area: BR-470 ( $n=16)$, MGAN ( $n=13)$, SC-370 ( $n=14)$ and BR-116 ( $n=13)$ (Fig. 2, Appendix 1). The collected specimens were anesthetized, euthanized with lidocaine (CFMV № 714/2002), fixed in a solution of formalin $10 \%$, preserved in a solution of alcohol $70 \%$ and deposited in the Coleção Zoológica da Universidade Regional de Blumenau (Appendix 3).

\section{Data analysis}

The sum of the higher abundance recorded for each species in each breeding site during sampling campaigns was used as the value of abundance of each area for the following diversity analysis (Table 1).

Rarefaction curves based on abundance were done using the iNEXT package (Hsieh et al., 2016) in R environment (R Core Team, 2020) to compare local richness among the four taxocenoses. In this analysis, the curves were generated by rarefaction/extrapolation of the values of richness and abundance from each taxocenose (Hill's number $q=0$ ), resulting in a curve with the value of observed and estimated richness (the standard function remained, with it being twice the sample size) (Chao et al., 2014). This analysis also calculates the index of Chao's richness which is an asymptote analysis (Hsieh et al., 2016). To evaluate whether the anuran taxocenoses were well represented by the sampling effort in all localities, the sample completeness curves analysis was performed using the iNEXT package (Hsieh et al., 2016) in $R$ environment ( $R$ Core Team, 2020).

The LCBD (Local Contribution of Beta Diversity - comparative indicators of the ecological uniqueness of the site) and SCBD (Species contribution of Beta Diversity - associated to degree of abundance, occupancy, niche position, niche breadth and species traits) (Heino \& 
Table 1. List of species with their respective abundance values of anuran taxocenoses sampled in the four studied localities: BR-470 highway between Ilhota and Indaial municipalities (BR-470), Santa Catarina state; Angelina and Major Gercino municipalities (MGAN), Santa Catarina state; SC-370 highway in Urubici municipality (SC-370), Santa Catarina state; and BR-116 highway between Curitiba and Mandirituba municipalities (BR-116), Paraná state.

\begin{tabular}{|c|c|c|c|c|}
\hline Taxon & 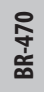 & 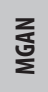 & 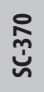 & $\frac{\circ}{\frac{1}{\dot{c}}}$ \\
\hline \multicolumn{5}{|l|}{ Family Brachycephalidae (2) } \\
\hline Ischnocenma henselii (Peters, 1870) & 0 & 1 & 1 & 4 \\
\hline Ischnocnema manezinho (Garcia, 1996) & 0 & 1 & 0 & 0 \\
\hline \multicolumn{5}{|l|}{ Family Bufonidae (2) } \\
\hline Rhinella abei (Baldissera, Caramaschi \& Haddad, 2004) & 9 & 2 & 0 & 5 \\
\hline Rhinella icterica (Spix, 1824) & 1 & 3 & 12 & 4 \\
\hline \multicolumn{5}{|l|}{ Family Centrolenidae (1) } \\
\hline Vitreorana uranoscopa (Müller, 1924) & 0 & 10 & 3 & 4 \\
\hline \multicolumn{5}{|l|}{ Family Cycloramphidae (1) } \\
\hline Cycloramphus bolitoglossus (Werner, 1897) & 0 & 0 & 0 & 1 \\
\hline \multicolumn{5}{|l|}{ Family Craugastoridae (1) } \\
\hline Haddadus binotatus (Spix, 1824) & 0 & 1 & 0 & 0 \\
\hline \multicolumn{5}{|l|}{ Family Hemiphractidae (1) } \\
\hline $\begin{array}{l}\text { Fritziana mitus Walker, Wachlevski, Nogueira da Costa, Nogueira-Costa, } \\
\text { Garcia \& Haddad, } 2018\end{array}$ & 2 & 15 & 0 & 0 \\
\hline \multicolumn{5}{|l|}{ Family Hylidae (22) } \\
\hline Aplastodiscus albosignatus (Lutz \& Lutz, 1938) & 0 & 0 & 0 & 13 \\
\hline Aplastodiscus perviridis Lutz, 1950 & 0 & 0 & 2 & 9 \\
\hline Boana albopunctata (Spix, 1824) & 0 & 0 & 0 & 16 \\
\hline Boana bischoffi (Boulenger, 1887) & 10 & 10 & 12 & 17 \\
\hline Boana faber (Wied-Neuwied, 1821) & 9 & 17 & 7 & 3 \\
\hline Boana guentheri (Boulenger, 1886) & 16 & 0 & 0 & 0 \\
\hline Boana joaquini (Lutz, 1968) & 0 & 0 & 5 & 0 \\
\hline Boana prasina (Burmeister, 1856) & 0 & 0 & 0 & 5 \\
\hline Bokermannohyla circumdata (Cope, 1871) & 0 & 0 & 0 & 3 \\
\hline Bokermannohyla hylax (Heyer, 1985) & 0 & 1 & 0 & 0 \\
\hline Dendropsophus microps (Peters, 1872) & 15 & 20 & 0 & 3 \\
\hline Dendropsophus minutus (Peters, 1872) & 8 & 20 & 39 & 21 \\
\hline Dendropsophus nahdereri (Lutz \& Bokermann, 1963) & 0 & 5 & 31 & 0 \\
\hline Dendropsophus sanborni (Schmidt, 1944) & 0 & 0 & 0 & 29 \\
\hline Dendropsophus werneri (Cochran, 1952) & 20 & 20 & 0 & 0 \\
\hline
\end{tabular}

Grönroos, 2016) were used to compare the species composition of four sampled taxocenoses using the data of richness and abundance with the function beta.div (Legendre \& Cáceres, 2013). In this analysis, the abundance data was transformed by the Hellinger method (Legendre \& Legendre, 2012).

These four taxocenoses were compared with other taxocenoses of the southern region of Brazil (Machado et al., 1999; Bernarde \& Machado, 2000; Machado \& Bernarde, 2002; Conte \& Machado, 2005; Conte \& RossaFeres, 2006; Machado \& Bernarde, 2006; Conte \& RossaFeres, 2007; Deiques et al., 2007; Colombo et al., 2008; Hartmann et al., 2008; Lucas \& Forte, 2008; Armstrong \& Conte, 2010; Kwet et al., 2010; lop et al., 2011; Lucas \& Marocco, 2011; Garey \& Hartmann, 2012; Giasson, 2012; Bastiani \& Lucas, 2013; Bolzan et al., 2014; Crivellari et al., 2014; Moreira et al., 2014; Santos \& Conte, 2014; Wachlevski \& Rocha, 2014; Nazaretti \& Conte, 2015; Bolzan et al., 2016; Leivas \& Hiert, 2016; Santos-Pereira et al., 2016; Ceron et al., 2017; De Lucca et al., 2017) to observe how are they grouped only using the data on richness (presence-absence). Only the species which have been identified to a specific level were used to

\begin{tabular}{|c|c|c|c|c|}
\hline Taxon & $\begin{array}{l}\stackrel{0}{y} \\
\frac{1}{\dot{y}}\end{array}$ & 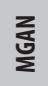 & 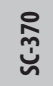 & $\frac{\circ}{\frac{0}{\dot{\varphi}}}$ \\
\hline Ololygon rizibilis (Bokermann, 1964) & 0 & 2 & 0 & 0 \\
\hline Scinax fuscovarius (Lutz, 1925) & 10 & 20 & 0 & 3 \\
\hline Scinax imbegue Nunes, Kwet \& Pombal Jr., 2012 & 0 & 39 & 0 & 0 \\
\hline Scinax perereca Pombal Jr., Haddad \& Kasahara, 1995 & 10 & 15 & 26 & 20 \\
\hline Scinax tymbamirim Nunes, Kwet \& Pombal Jr., 2012 & 12 & 35 & 0 & 0 \\
\hline Sphaenorhynchus surdus (Cochran, 1953) & 0 & 0 & 15 & 6 \\
\hline Sphaenorhynchys caramaschii Toledo, Garcia, Lingnau \& Haddad, 2007 & 14 & 0 & 0 & 18 \\
\hline \multicolumn{5}{|l|}{ Family Hylodidae (1) } \\
\hline Hylodes perplicatus (Miranda-Ribeiro, 1926) & 0 & 15 & 0 & 0 \\
\hline \multicolumn{5}{|l|}{ Family Leptodactylidae (10) } \\
\hline Adenomera araucaria Kwet \& Ângulo, 2002 & 0 & 50 & 1 & 1 \\
\hline Adenomera engelsi Kwet, Steiner \& Zillikens, 2009 & 0 & 1 & 0 & 0 \\
\hline Adenomera nana (Müller, 1922) & 20 & 50 & 0 & 6 \\
\hline Leptodactylus latrans (Steffen, 1815) & 9 & 34 & 13 & 9 \\
\hline Leptodactylus notoaktites Heyer, 1978 & 5 & 0 & 0 & 4 \\
\hline Leptodactylus plaumanii Ahl, 1936 & 0 & 0 & 6 & 0 \\
\hline Physalaemus aff. gracilis & 0 & 0 & 25 & 10 \\
\hline Physalaemus cuvieri Fitzinger, 1826 & 12 & 4 & 25 & 8 \\
\hline Physalaemus lateristriga (Steindachner, 1864) & 8 & 20 & 0 & 1 \\
\hline Physalaemus nanus (Boulenger, 1888) & 13 & 24 & 16 & 0 \\
\hline \multicolumn{5}{|l|}{ Family Odontophrynidae (3) } \\
\hline Odontophrynus americanus (Duméril \& Bibron, 1841) & 0 & 0 & 0 & 1 \\
\hline Proceratophrys boiei (Wied-Neuwied, 1824) & 4 & 5 & 0 & 1 \\
\hline Proceratophrys brauni Kwet \& Faivovich, 2001 & 0 & 0 & 0 & 20 \\
\hline \multicolumn{5}{|l|}{ Family Phyllomedusidae (1) } \\
\hline Phyllomedusa distincta Lutz, 1950 & 26 & 7 & 0 & 0 \\
\hline \multicolumn{5}{|l|}{ Family Ranidae (1) } \\
\hline Lithobates catesbeianus (Shaw, 1802) & 15 & 0 & 3 & 21 \\
\hline Richness & 22 & 29 & 18 & 30 \\
\hline Abundance & 241 & 447 & 242 & 254 \\
\hline
\end{tabular}

compose the richness of the aforementioned studies, therefore the unidentified species affinis and confer were excluded from the analysis. The $\beta j a c$ (overall beta diversity - Jaccard dissimilarity) was calculated using betapart function (Baselga, 2010). In this analysis the beta diversity is partitioned in two components: turnorver ( $\beta$ jtu) and nestedness ( $\beta$ jne). In the beta partitioning analysis these two components will give the proportional information of species substituition (turnorver) and species loss (nestedness) of the overall beta diversity ( $\beta$ jac) and identify which component is predominant (Baselga, 2010). A cluster analysis was made only using the $\beta$ jac index with the same dissimilarity matrix from beta partitioning analysis, adopting as a criterion a dissimilarity value of $40 \%$. This analysis was performed with the MASS package (Venables \& Ripley, 2002) in R (R Core Team, 2020). The Mantel test was used to identify the influence of geographical distances in species composition, using a dissimilarity matrix of geographical distances (euclidean distances), with latitudinal and longitudinal coordinates of each location and with the dissimilarity matrices ( $\beta$ jac, $\beta j t u, \beta j n e)$ from the beta partitioning analysis. This analysis was performed with the vegan and MASS packages 


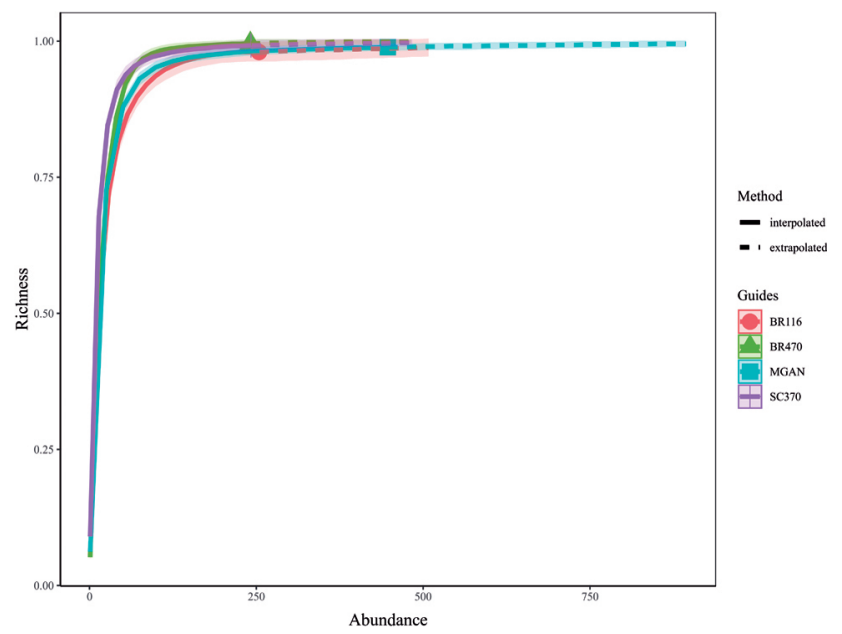

Figure 3. Sample completeness curves with their respective confidence intervals (95\%) of the four sampled anuran taxocenoses: BR-470 highway between Ilhota and Indaial municipalities (BR-470), Santa Catarina state; Angelina and Major Gercino municipalities (MGAN), Santa Catarina state; SC-370 highway in Urubici municipality (SC-370), Santa Catarina state; and BR-116 highway between Curitiba and Mandirituba municipalities (BR-116), Paraná state.

(Venables \& Ripley, 2002; Oksanen et al., 2019) in R environment (R Core Team, 2020).

\section{RESULTS}

A total of 46 species of anurans were registered in this study: BR-116 (30 spp., 65\% of the total), MGAN (29 spp., 63\%), BR-470 (22 spp., 47\%) and SC-370 (18 spp., 39\%) (Table 1). The sample completeness curves showed the diversity of anuran taxocenoses were well represented by the sampling effort (Fig. 3).

The rarefaction/extrapolation curves showed a difference of richness within the anuran taxocenoses of BR-116 and MGAN in relation of the anuran taxocenoses of BR-470 and SC-370, both on interpolation and on extrapolation (Fig. 4). Only the MGAN and BR-116 taxocenoses differed in the values of Chao's richness in the asymptotic analysis (Table 2 ).

The species composition was not different among the four taxocenoses by LCBD index (Table 3). The sum of squares (total SS) was of 1,41 and the beta diversity was of 0,47 (total BD). The eight species that better contributed to the beta diversity with the biggest SCBD scores were: Dendropsophus sanborni $(0,062), D$. nahdereri $(0,061)$, Physalaemus aff. grracilis $(0,054)$, Adenomera nana $(0,049), A$. araucaria $(0,048)$, Scinax imbegue $(0,047)$, S. tymbamirim $(0,047)$ and $D$. werneri $(0,046)$ (see Appendix 4 for all species).

The overall beta diveristy for all taxocenoses from the southern region of Brazil was 0,962 ( $\beta$ jac) and the turnover component ( $\beta$ jtu $=0,949$ ) was predominant to nestedness component ( $\beta$ jne $=0,012$ ). The species composition is influenced by the geographical distances (Mantel $-r=0,669, p<0,01$ ) as well as the turnover component (Mantel $-r=0,636, p<0,01$ ), but not the nestedness component (Mantel $-r=-0,264, p=1,00$ ).

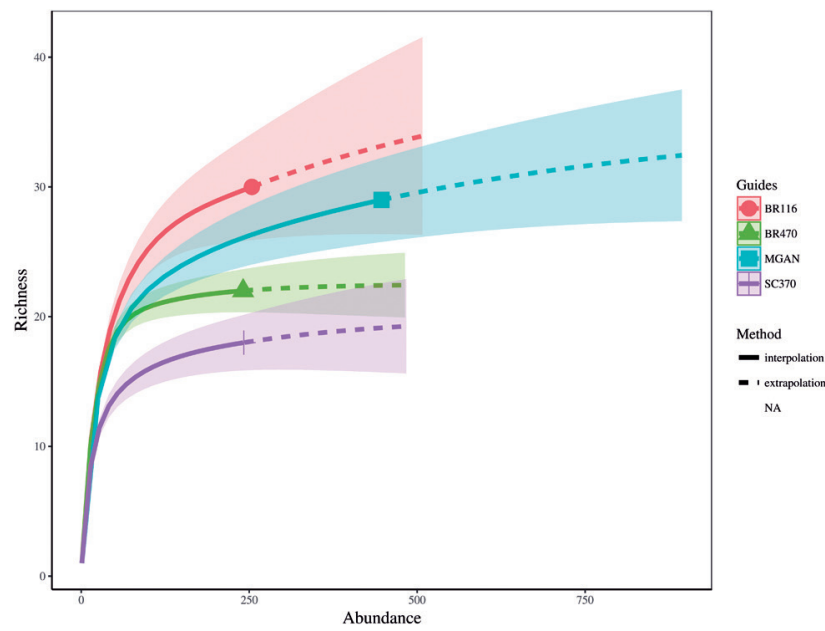

Figure 4. Rarefaction/extrapolation curves with their respective confidence intervals (95\%) of the four sampled anuran taxocenoses: BR-470 highway between Ilhota and Indaial municipalities (BR-470), Santa Catarina state; Angelina and Major Gercino municipalities (MGAN), Santa Catarina state; SC-370 highway in Urubici municipality (SC-370), Santa Catarina state; and BR-116 highway between Curitiba and Mandirituba municipalities (BR-116), Paraná state.

Table 2. Index of Chao's richness of the asymptotic analysis for the four taxocenoses of anurans: BR-470 highway between Ilhota and Indaial municipalities (BR-470), Santa Catarina state; Angelina and Major Gercino municipalities (MGAN), Santa Catarina state; SC-370 highway in Urubici municipality (SC-370), Santa Catarina state; and BR-116 highway between Curitiba and Mandirituba municipalities (BR-116), Paraná state.

\begin{tabular}{cccccc}
\hline \multirow{2}{*}{ Locality } & \multicolumn{3}{c}{ Chao's richness } & \multicolumn{2}{c}{ Confidence interval (95\%) } \\
\cline { 2 - 6 } & Observed & Estimated & Standard Error & Lower & Upper \\
\hline MGAN & 29 & 35.23 & 7.53 & 29.97 & 69.04 \\
BR-470 & 22 & 22.49 & 1.31 & 22.02 & 30.41 \\
SC-370 & 18 & 19.99 & 3.72 & 18.18 & 40.04 \\
BR-116 & 30 & 39.96 & 10.32 & 31.86 & 83.11 \\
\hline
\end{tabular}

Table 3. LCBD index values (Local Contribution of Beta Diversity) for the anuran taxocenoses: BR-470 highway between Illhota and Indaial municipalities (BR-470), Santa Catarina state; Angelina and Major Gercino municipalities (MGAN), Santa Catarina state; SC-370 highway in Urubici municipality (SC-370), Santa Catarina state; and BR-116 highway between Curitiba and Mandirituba municipalities (BR-116), Paraná state.

\begin{tabular}{ccc}
\hline Locality & LCBD & $\mathbf{p}(<\mathbf{0 . 0 5})$ \\
\hline MGAN & 0.25 & 0.47 \\
BR-470 & 0.20 & 0.93 \\
SC-370 & 0.28 & 0.13 \\
BR-116 & 0.25 & 0.39 \\
\hline
\end{tabular}

The result of the cluster analysis separated the four taxocenoses, grouping them with other localities from the southern region of Brazil (Fig. 5). Out of all the studied taxocenoses, only BR-116 and MGAN were similar to the clusters that they formed by the $40 \%$ criterion of dissimilarity. It was possible to observe some groups related to the geographical distances, vegetation and landscapes, such as the Pampas and Restinga of the Rio Grande Do Sul areas (Sentinela do Sul/RS, PE Itapeva, APA Ibirapuitã, FEPA), among the coastal areas of Serra do Mar and Serra 

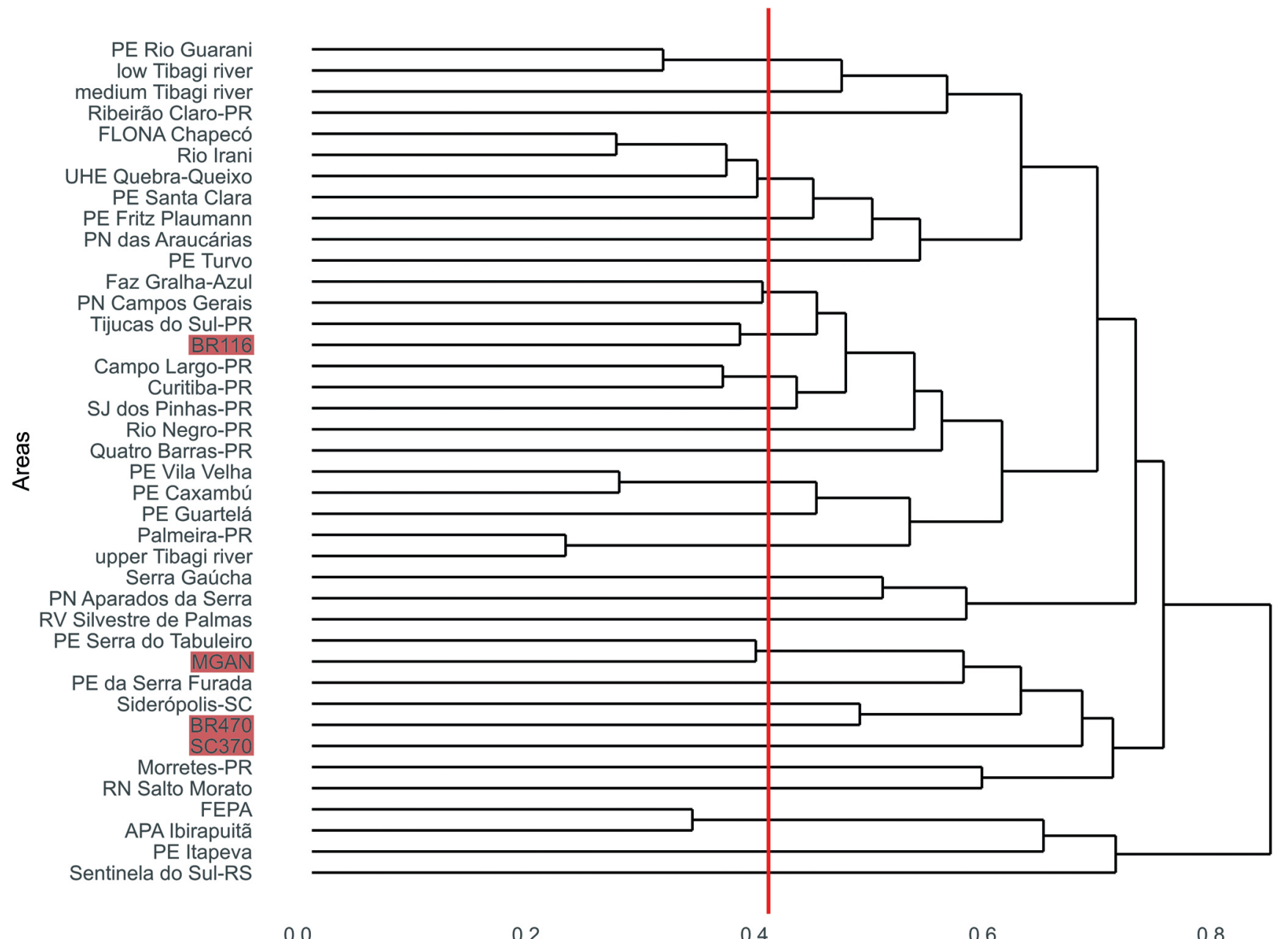

0.0

0.2

0.4

0.6

0.8

Figure 5. Dendrogram from cluster analysis with the Jaccard index method (dissimilarity shown by Weight 1-Jaccard index) grouping the four anuran taxocenoses (red highlight - BR-470, MGAN, SC-370 and BR-116) with other taxocenoses from the southern region of Brazil (Table 3). The red line represents the criterion of $40 \%$ dissimilarity.

Geral of Santa Catarina and Paraná (RN Salto Morato, Morretes/PR, SC-370, Siderópolis-SC, BR-470, PE da Serra Furada, PE da Serra do Tabuleiro, MGAN), among the grassland areas of Paraná and the first paranaense plateau (upper Tibagi river, Palmeira/PR, PE Guartelá, PE Caxambú, PE Vila Velha - Quatro Barras/PR, Rio Negro/ PR, SJ dos Pinhais/PR, Campo Largo/PR, Curitiba/PR, Tijucas do Sul/PR, BR-116, PN Campos Gerais and Faz Gralha-Azul), among the western Santa Catarina, Paraná and Rio Grande Do Sul areas (PE Turvo, PN das Araucárias, PE Fritz Plaumann, PE Santa-Clara, UHE Quebra-Queixo, FLONA Chapecó, Rio Irani) and among the medium and low Tibagi river areas (Ribeirão Claro/PR, medium Tibagi river, PE Rio Guarani and low Tibagi river) (Fig. 5).

\section{DISCUSSION}

BR-116 and MGAN presented the highest richness, and BR-470 and SC-370 the lowest richness among the study areas. All sampled breeding sites at MGAN were at small rural properties, away from large urban centers and highways, in a countryside region near the Serra do Tabuleiro in the Santa Catarina state. Most of the sampled breeding sites were in well preserved permanent preservation areas (APP) of a small hydropower plant reservoir between Major Gercino and Angelina municipalities. The other areas are urban centers and highways with medium to great flow of vehicles within these three areas, with many commercial, industrial and agricultural properties. The fieldworks in these areas were conducted along the highways. The high richness of anuran species at BR-116 might be explained by many breeding sites being a little farther away from the highway, in forest environments or on the edge of well preserved fragments. The other two areas (BR-470 and SC-370) have less species richness with similar environmental impacts (many disturbed open land environments). Nevertheless, in remark of the LCBD among these four taxocenoses, none of them have a unique species composition (Legendre \& Cáceres, 2013).

The species that better contributed to the beta diversity (SCBD) are less generalist and present narrow niches (Heino \& Grönroos, 2016). Taking that into account, the SCBD analysis for the four studied taxocenoses showed some interesting ecological aspects. First in relation to the species distribution, where Scinax imbegue, S. tymbamirim and Dendropsophus werneri are distributed in lowlands and coastal regions of Serra do Mar in Atlantic Forest (Pombal Jr. \& Bastos, 1998; Nunes et al., 2012). 
These three species were registered with higher abundance only at the breeding sites of BR-470 and MGAN (Table 1). D. nahdereri and Physalaemus aff. gracilis are distributed in highlands and mountain regions of subtropical Atlantic Forest (Nascimento et al., 2005; Conte et al., 2010; Kwet et al., 2010). These two species were registered with higher abundance at the breeding sites of SC-370 and BR-116 (Table 1). D. sanborni is distributed in highlands and grassland vegetation from the central-west to southern Brazil (Gavira et al., 2016). This species was registered with higher abundance at the breeding sites of BR-116 (Table 1). However, these six species are characterized by their tendency to occupy open land or edge forest breeding sites. Adenomera araucaria and A. nana are distributed in lowlands and highlands of subtropical Atlantic Forest and found only in forest breeding sites, even in urban forest fragments (Kwet \& Angulo, 2002; Conte et al., 2010), due to their terrestrial reproduction mode (Heyer, 1973; Kwet et al., 2010). The two Adenomera species were registered with higher abundance at forest fragments of MGAN and BR-470 (Table 1).

The influence of geographic distances in anuran species composition was also evidenced in other studies (Bertoluci et al., 2007; Lucas \& Fortes, 2008; lop et al., 2011; Almeida-Gomes \& Rocha, 2014; Bolzan et al., 2014) and the turnover is the major component that explains the differences of species composition of subtropical Atlantic Forest. The association between the turnover and geographical distances may be related to the differences in climate, phytophysionomy and landscape (Vasconcelos et al., 2014), in which the groups of cluster analysis have some correlation with the sub-regions of subtropical Atlantic Forest (Garcia et al., 2007).

The few similarities within species composition of the areas studied may be also associated to habitat quality. The BR-116 and MGAN anuran taxocenoses are similar to two other taxocenoses within well preserved localities: Parque Estadual da Serra do Tabuleiro and Tijucas do Sul/PR, while the BR-470 anuran taxocenose (northern region of Santa Catarina state) is grouped with the anuran taxocenose of Siderópolis (southern region of Santa Catarina state). There is coal mining in the Siderópolis region, which is an activity that negatively affects the environment (De Lucca et al., 2017). Thus, this area is grouped, but not similar to the impacted area and the differences of species composition might be related to the effect of environmental impacts.

\section{CONCLUSIONS}

The subtropical anuran taxocenoses differences on species composition seem associated to changes of phytophysionomy, landscape and geographic distances. The highest richness at BR-116 and MGAN may relate to habitats of higher quality, as these taxocenoses are similar to other well preserved areas from the subtropical Atlantic Forest. The lowest richness found in the BR-470 and SC-370 anuran taxocenoses may be related to low habitat quality. Regardless, the data gathered points to the importance of preservation and maintenance of forest fragments, even in agricultural and urban environments due to the possibility that these fragments may hold valuable biodiversity.

\section{ACKNOWLEDGEMENTS}

For the opportunity to carry out theses studies, I am grateful André Felipe Testoni, Célio Testoni, Diego Pérez and Josias Alan Rezini; to the IBAMA for the collecting permits (№ 233/2010, № 80/2010-NUFAU/ SC, № 173/2010-NUFAU/SC, № 05/2012); for helping during the field works, I am grateful to Josias Alan Rezini, Fernando Venâncio, Beatrice Stein, Carlos Alberto Borchardt-Júnior, Danilo Capela and Guilherme Grazzini; to the Conselho Nacional de Desenvolvimento Científico e Tecnológico (CNPq processes 167888/2014-5); and for the English revision, I am grateful to Camila Tortul Ferriolli.

\section{REFERENCES}

Ab'saber, A.N. 1977. Os domínios morfoclimáticos na América do Sul. Geomorfologia, São Paulo, 52: 1-23.

Almeida-Gomes, M. \& Rocha, C.F.D. 2014. Landscape connectivity may explain anuran species distribution in an Atlantic forest fragmented area. Landscape Ecology, 29(1): 29-40. DOI

Armstrong, C.G. \& Conte, C.E. 2010. Taxocenose de anuros (Amphibia: Anura) em uma área de Floresta Ombrófila Densa no sul do Brasil. Biota Neotropica, 10(1): 39-46. DOI

Baselga, A. 2010. Partitioning the turnover and nestedness components of beta diversity. Global Ecology and Biogeography, 19: 134-143.

Bastiani, V.I.M.D. \& Lucas, E.M. 2013. Anuran diversity (Amphibia, Anura) in a Seasonal Forest fragment in southern Brazil. Biota Neotropica, 13: 255-264. DOI

Bernarde, P.S. \& Machado, R.A. 2000. Riquezas de espécies, ambientes de reproduçáo e temporada da vocalização anurofauna em três barras do Paraná, Brasil (Amphibia: Anura). Cuadernos de Herpetologia, 14(2): 93-104.

Bertoluci, J.; Brassaloti, R.A.; Ribeiro-Júnior, J.W.; Vilela, V.M.D.F.N. \& Sawakuchi, H.0. 2007. Species composition and similarities among anuran assemblages of forest sites in southeastern Brazil. Scientia Agricola, 64(4): 364-374. DOI

Bolzan, A.M.R.; Hartmann, P.A. \& Hartmann, M.T. 2014. Diversidade de anfíbios anuros de uma área de Pampa no município de São Gabriel, Rio Grande do Sul, Brasil. Iheringia, Série Zoologia, 104(3): 277-283. D0l

Bolzan, A.M.R.; Saccol, S.A. \& Santos, T.G.D. 2016. Composition and diversity of anurans in the largest conservation unit in Pampa biome, Brazil. Biota Neotropica, 16(2): e20150113. D0I

Ceron, K.; Lucas, E.M. \& Zocche, J.J. 2017. Anurans of Parque Estadual da Serra Furada, Santa Catarina, Southern Brazil. Herpetology Notes, 10: 287-296. https://www.biotaxa.org/hn/article/view/23873.

Chao, A.; Gotelli, N.J.; Hsieh, T.C.; Sander, E.L.; Ma, K.H.; Colwell, R.K. \& Ellison, A.M. 2014. Rarefaction and extrapolation with Hill numbers: a framework for sampling and estimation in species diversity studies. Ecological Monographs, 84(1): 45-67.

Colombo, P.; Kindel, A.; Vinciprova, G. \& Krause, L. 2008. Composição e ameaças à conservação dos anfíbios anuros do Parque Estadual de 
Itapeva, município de Torres, Rio Grande do Sul, Brasil. Biota Neotropica, 8(3): 229-240. DOI

Conte, C.E. 2010. Diversidade de Anfíbios da Floresta com Araucária. (Doctoral Thesis). São José do Rio Preto, SP, Universidade Estadual Paulista.

Conte, C.E. \& Machado, R.A. 2005. Riqueza de espécies e distribuição espacial e temporal em comunidade de anuros (Amphibia, Anura) em uma localidade de Tijucas do Sul, Paraná, Brasil. Revista Brasileira de Zoologia, 22(4): 940-948. DOI

Conte, C.E. \& Rossa-Feres, D.D.C. 2006. Diversidade e ocorrência temporal da anurofauna (Amphibia, Anura) em São José dos Pinhais, Paraná, Brasil. Revista Brasileira de Zoologia, 23(1): 162-175. D0I

Conte, C.E. \& Rossa-Feres, D.D.C. 2007. Riqueza e distribuição espaçotemporal de anuros em um remanescente de Floresta de Araucária no sudeste do Paraná. Revista Brasileira de Zoologia, 24(4): 1025-1037. DOl

Conte, C.E.; Nomura, F.; Machado, R.A.; Kwet, A.; Lingnau, R. \& Rossa-Feres, D.D.C. 2010. Novos registros na distribuição geográfica de anuros na Floresta com Araucária e considerações sobre suas vocalizações. Biota Neotropica, 10(2): 201-224. D0I

Crivellari, L.B.; Leivas, P.T.; Leite, J.C.M.; Gonçalves, D.D.S.; Mello, C.M.; RossaFeres, D.D.C. \& Conte, C.E. 2014. Amphibians of grasslands in the state of Paraná, southern Brazil (Campos Sulinos). Herpetology Notes, 7: 639-654. https://biotaxa.org/hn/article/view/8558.

Crump, M.L. \& Scott Jr., N.J. 1994. Visual Encounters. In: Heyer, W.R.; Donnelly, M.A.; Mcdiarmid, R.W.; Hayek, L.A.C.; Foster, M.S. (Eds.). Measuring and monitoring biological diversity standard methods for amphibians. Washington, D.C., Smithsonian Institution Press. p. 84-92.

Cushman, S.A. 2006. Effects of habitat loss and fragmentation on amphibians: A review and prospectus. Biological Conservation, 128(2): 231-240. D0I

De Lucca, G.S.; Barros, F.A.; Oliveira, J.V.; Dal Magro, J. \& Lucas, E.M. 2017. The role of environmental factors in the composition of anuran species in several ponds under the influence of coal mining in southern Brazil. Wetlands Ecology and Management, 26(3): 1-13. DOI

Deiques, C.H.; Stahnke, L.F.; Reinke, M. \& Schmitt, P. 2007. Guia ilustrado dos anfíbios e répteis do Parque Nacional de Aparados da Serra, Rio Grande do Sul, Santa Catarina, Brasil. Porto Alegre, USEB.

Garcia, P.C.A.; Lavilla, E.; Langone, J. \& Segalla, M.V. 2007. Anfíbios da região subtropical da América do Sul Padrões de Distribuição. Ciência \& Ambiente, 1: 65-100.

Garey, M.V. \& Hartmann, M.T. 2012. Anurans of Reserva Natural Salto Morato, municipality of Guaraqueçaba, State of Paraná, southern Brazil. Biota Neotropica, 12(4): 137-145. DOI

Gavira, S.B.; Gaia, L.0. \& Balestieri, J.B.P. 2016. New record of Dendropsophus sanborni (Schmidt, 1944), in the Central-West Region of Brazil. Herpetozoa, 29(1/2): 96-97. https://www.zobodat.at/pdf/ HER $291220096-0097 . p d f$.

Giasson, L.0.M. 2012. Anfíbios. In: Cherem, J.J. \& Salmoria, V. (Eds.). Fisiografia, florae fauna do Rio Irani. Florianópolis, SC, ETS Energia Transporte e Saneamento. p. 83-101.

Haddad, C.F.B. \& Prado, C.P.A. 2005. Reproductive modes in frogs and their unexpected diversity in the Atlantic Forest of Brazil. BioScience, 55(3): 207-217.

Haddad, C.F.B.; Toledo, L.F.; Prado, C.P.A.; Loebmann, D.; Gasparini, J.L. \& Sazima, I. 2013. Guia dos anfibios da Mata Atlântica: diversidade e biologia. São Paulo, Anolis Books.

Hartmann, M.T.; Garcia, P.C.A.; Giasson, L.0.M. \& Hartmann, P.A. 2008. Anfíbios. In: Cherem, J.J.; Kammers, M. (Eds.). A fauna das áreas de influência da Usina Hidrelétrica Quebra Queixo. Erechim, RGS, Habilis. p. 89-110.

Heino, J. \& Grönroos, M. 2016. Exploring species and site contributions to beta diversity in stream insect assemblages. Oecologia, 183(1): 151-160. D0I
Heyer, W.R. 1973. Systematics of the marmoratus group of the frog genus Leptodactylus (Amphibia, Leptodactylidae). Contributions in Scince, 251: $1-50$.

Hsieh, T.C.; Ma, K.H. \& Chao, A. 2016. iNEXT: an R package for rarefaction and extrapolation of species diversity (Hill numbers). Methods in Ecology and Evolution, 7(12): 1451-1456.

Instituto Chico Mendes de Conservação da Biodiversidade (ICMBio). 2018. Anfíbios. In: ICMBio - Instituto Chico Mendes de Conservação da Biodiversidade, Livro Vermelho da fauna brasileira ameaçada de extinção. Brasília, DF, ICMBio/MMA. v. 5, 129p.

International Union for Conservation of Nature and Natural Resources (IUCN). 2020. The IUCN Red List of Threatened Species. Version 2020-2. Available: https://www.iucnredlist.org. Access: 04/09/2020.

lop, S.; Caldart, V.M.; dos Santos, T.G. \& Cechin, S.Z. 2011. Anurans of Turvo State Park: testing the validity of Seasonal Forest as a new biome in Brazil. Journal of Natural History, 45: 2443-2461.

Kwet, A. \& Angulo, A. 2002. A new species of Adenomera (Anura, Leptodactylidae) from the Araucaria forest of Rio Grande do Sul (Brazil), with comments on the systematic status of southern populations of the genus. Alytes, 20(1-2): 28-43.

Kwet, A.; Lingnau, R. \& Di-Bernardo, M. 2010. Pró-Mata: Anfibios da Serra Gaúcha, sul do Brasil-Amphibien der Serra Gaúcha, SüdbrasilienAmphibians of the Serra Gaúcha, South of Brazil. 2.ed. Tübingen, BrasilienZentrum University of Tübingen/EDIPUCRS.

Legendre, P. \& Cáceres, M. 2013. Beta diversity as the variance of community data: dissimilarity coefficients and partitioning. Ecology Letters, 16(8): 951-963. DOI

Legendre, P. \& Legendre, L.F. 2012. Numerical ecology. Amsterdam, Elsevier.

Leivas, P.T. \& Hiert, C. 2016. Anuran richness (Amphibia: Anura) in remnants of Araucaria Forest, Paraná, Brazil. Herpetology Notes, 9: 15-21. https:// biotaxa.org/hn/article/view/12170.

Lucas, E.M. \& Fortes, V.B. 2008. Frog diversity in the Floresta Nacional de Chapecó, Atlantic Forest of southern Brazil. Biota Neotropica, 8(3): 51-61. DOI

Lucas, E.M. \& Marocco, J.C. 2011. Anurofauna (Amphibia, Anura) em um remanescente de floresta ombrófila mista no Estado de Santa Catarina, Sul do Brasil. Biota Neotropica, 11(1): 377-384. D01

Machado, R.A. \& Bernarde, P.S. 2002. Anurofauna da bacia do rio Tibagi. In: Medri, M.E.; Bianchini, E.; Shibatta, 0.A. \& Pimenta, J.A. (Eds.). A Bacia do Rio Tibagi. Londrina, Universidade Estadual de Londrina. p. 297-306.

Machado, R.A. \& Bernarde, P.S. 2006. Anfíbios Anuros do Parque Estadual Mata dos Godoy. In: Torezan, J.M.D. (Ed.). Ecologia do Parque Estadual Mata do Godoy. Paraná. Londrina, Instituto de Tecnologia e Desenvolvimento Econômico e Social (ITEDES). p. 105-110.

Machado, R.A.; Bernarde, P.S.; Morato, S.A.A. \& Anjos, L.D. 1999. Análise comparada da riqueza de anuros entre duas áreas com diferentes estados de conservação no município de Londrina, Paraná, Brasil (Amphibia, Anura). Revista Brasileira de Zoologia, 16(4): 997-1004. D01

Moreira, L.F.B.; Knauth, D.S. \& Maltchik, L. 2014. Checklist of amphibians in a rice paddy area in the Uruguayan savanna, southern Brazil. Check List, 10(5): 1014-1019. DOI

Myers, N.; Mittermeier, R.A.; Mittermeier, C.G.; Fonseca, G.A.B. \& Kent, J. 2000. Biodiversity hotspots for conservation priorities. Nature, London, 403: 853-858.

Nascimento, L.B.; Caramaschi, U. \& Cruz, C.A.G. 2005. Taxonomic Review of the Species groups of the genus Physalaemus Fitzinger, 1826 with revalidation of the genera Engystomops Jiménez-de-la-Espada, 1872 and Eupemphix Steindachner, 1863 (Amphibia, Anura, Leptodactylidae). Arquivos do Museu Nacional, 63(2): 297-320. 
Nazaretti, E.M. \& Conte, C.E. 2015. Anurofauna an altered remant of mesophytic semideciduous forest the banks of the Paranapanema River. Iheringia, Série Zoologia, 105(4): 420-429. DOI

Nunes, I.; Kwet, A. \& Pombal, J.P. 2012. Taxonomic Revision of the Scinax alter Species Complex (Anura: Hylidae). Copeia, 2012(3): 554-569.

Oksanen, J.; Blanchet, F.G.; Friendly, M.; Kindt, R.; Legendre, P.; McGlinn, D.; Minchin, P.R.; O'Hara, R.B.; Simpson, G.L.; Solymos, P.; Stevens, M.H.H.; Szoecs, E. \& Wagner, H. 2019. vegan: Community Ecology Package. R package version 2.5-6. https://CRAN.R-project.org/package=vegan.

Pombal Jr., J.P. \& Bastos, R.P. 1998. Nova espécie de Hyla Laurenti, 1768 do centro-oeste brasileiro e a posição taxonômica de $H$. microcephala werneri Cochran, 1952 e H. microcephala meridiana B. Lutz, 1952 (Anura, Hylidae). Boletim do Museu Nacional, série Zoologia, 390: 1-13.

R Core Team. 2020. R: A language and environment for statistical computing. R Foundation for Statistical Computing, Vienna, Austria. https://www.Rproject.org.

Ribeiro, M.C.; Metzger, J.P.; Martensen, A.C.; Ponzoni, F.J. \& Hirota, M.M. 2009. The Brazilian Atlantic Forest: How much is left, and how is the remaining forest distributed? Implications for conservation. Biological Conservation, 142(6): 1141-1153.

Santos, E.J. \& Conte, C.E. 2014. Richness and temporal distribution of anurans (Amphibia: Anura) in a Mixed Ombrophile Forest fragment. Iheringia, Série Zoologia, 104(3): 323-333. D0I

Santos-Pereira, M.; Milani, D.; Barata-Bittencourt, L.F.; lapp, T.M. \& Rocha, C.F.D. 2016. Anuran species of the Salto Morato Nature Reserve in Paraná, southern Brazil: review of the species list. Check List, 12(3): 1-11. DOI

Sazima, I. \& Eterovick, P.C. 2000. Structure of an anuran community in a montane meadow in southeastern Brazil: effects of seasonality, habitat, and predation. Amphibia-Reptilia, 21(4): 439-461.

Scott Jr., N.J. \& Woodward, B.D. 1994. Surveys at Breeding Sites. In: Heyer, W.R.; Donnelly, M.A.; Mcdiarmid, R.W.; Hayek, L.A.C.; Foster, M.S. (Eds.). Measuring and monitoring biological diversity standard methods for amphibians. Washington, D.C., Smithsonian Institution Press. p. 118-125.

Segalla, M.V.; Caramaschi, U.; Cruz, C.A.G.; Garcia, P.C.A.; Grant, T.; Haddad, C.F.B.; Santana, D.J.; Toledo, L.F.; Lagone, J.A. 2019. Brazilian amphibians: list of species. Herpetologia Brasileira, 8: 65-96.
Silva, F.R.; Candeira, C.P. \& Rossa-Feres, D.C. 2012a. Dependence of anuran diversity on environmental descriptors in farmland ponds. Biodiversity and Conservation, 21: 1411-1424.

Silva, F.R.; Oliveira, T.A.L.; Gibbs, J.P. \& Rossa-Feres, D.C. 2012b. An experimental assessment of landscape configuration effects on frog and toad abundance and diversity in tropical agro-savannah landscapes of southeastern Brazil. Landscape Ecology, 27: 87-96.

Silvano, D.L.; Colli, G.R.; Dixo, M.B.O.; Pimenta, B.V.S. \& Wiederhecker, H.C. 2003. Anfíbios e répteis. In: Rambaldi, D.M.; Oliveira, D.A.S. (Eds.). Fragmentação de ecossistemas: causas, efeitos sobre a biodiversidade e recomendações de políticas públicas. Brasília, Ministério do Meio Ambiente/Secretaria de Biodiversidade e Florestas. p. 183-200.

Vasconcelos, T.S.; Prado, V.H.M.; Silva, F.R. \& Haddad, C.F.B. 2014. Biogeographic Distribution Patterns and Their Correlates in the Diverse Frog Fauna of the Atlantic Forest Hotspot. PlosOne, 9(8): e104130. DOI

Vasconcelos, T.S.; Santos, T.G.; Rossa-Feres, D.C. \& Haddad, C.F.B. 2009. Influence of the environmental heterogeneity of breeding ponds on anuran assemblages from southeastern Brazil. Canadian Journal of Zoology, 87(8): 699-707. D01

Veloso, H.P.; Oliveira-Filho, L.D.; Vaz, A.M.S.F.; Lima, M.P.M.; Marquete, R. \& Brazao, J.E.M. 2012. Manual técnico da vegetação brasileira. Rio de Janeiro, IBGE.

Venables, W.N. \& Ripley, B.D. 2002. Modern Applied Statistics with S. New York, Springer.

Verdade, V.K.; Valdujo, P.H.; Carnaval, A.C.; Schiesari, L.; Toledo, L.F.; Mott, T.; Andrade, G.V.; Eterovick, P.C.; Menin, M.; Pimenta, B.V.S.; Nogueira, C.; Lisboa, C.S.; Paula, C.D. \& Silvano, D.L. 2012. A leap further: the Brazilian Amphibian Conservation Action Plan. Alytes, 29(1-4): 28-43.

Wachlevski, M. \& Rocha, C.F.D. 2014. Anfíbios anuros em uma área de Mata Atlântica da Serra do Tabuleiro, Santa Catarina. Biotemas, 27(2): 97-107. D0I

Young, B.E.; Lips, K.R.; Reaser, J.K.; Ibáñez, R.; Salas, A.W.; Cedeño, J.R.; Coloma, L.A.; Ron, S.; La Marca, E.; Meyer, J.R.; Muñoz, A.; Bolaños, F.; Chaves, G. \& Romo, D. 2001. Population declines and priorities for Amphibian conservation in Latin America. Conservation Biology, 15(5): 1213-1223. 


\section{APPENDIX 1}

Habitat and vegetation characterization for the sampled points for each studied locality: BR-470 - BR-470 highway between Ilhota and Indaial municipalities, Santa Catarina state; MGAN - between Angelina and Major Gercino municipalities, Santa Catarina state; SC-370 - SC-370 highway in Urubici municipality, Santa Catarina state; and BR-116 - BR-116 highway between Curitiba and Mandirituba municipalities, Paraná state.

\begin{tabular}{|c|c|c|c|c|c|}
\hline Locality & Site & Coordinates & Habitat & Aquatic Environment & Vegetation \\
\hline \multirow[t]{16}{*}{ BR-470 } & BR01 & $26^{\circ} 50^{\prime} 16.14^{\prime \prime} \mathrm{S}, 48^{\circ} 46^{\prime} 54.42^{\prime \prime} \mathrm{W}$ & forest edge & permanent lentic & taboos \\
\hline & BR02 & $26^{\circ} 50^{\prime} 16.50^{\prime \prime} \mathrm{S}, 48^{\circ} 47^{\prime} 17.04^{\prime \prime} \mathrm{W}$ & forest edge & permanent lentic & grass and shrubs \\
\hline & BR03 & $26^{\circ} 50^{\prime} 13.90^{\prime \prime} \mathrm{S}, 48^{\circ} 47^{\prime} 18.43^{\prime \prime} \mathrm{W}$ & forest & permanent lotic & arboreal and shrubs \\
\hline & BR04 & $26^{\circ} 50^{\prime} 21.96^{\prime \prime} \mathrm{S}, 48^{\circ} 47^{\prime} 21.00^{\prime \prime} \mathrm{W}$ & open area & permanent lentic & grass \\
\hline & BR05 & $26^{\circ} 50^{\prime} 16.74^{\prime \prime} \mathrm{S}, 48^{\circ} 47^{\prime} 18.72^{\prime \prime} \mathrm{W}$ & open area & permanent lentic & grass \\
\hline & BR06 & $26^{\circ} 50^{\prime} 34.74^{\prime \prime} \mathrm{S}, 48^{\circ} 47^{\prime} 42.96^{\prime \prime} \mathrm{W}$ & open area & permanent lentic & grasss and taboos \\
\hline & BR07 & $26^{\circ} 52^{\prime} 43.44^{\prime \prime} \mathrm{S}, 48^{\circ} 50^{\prime} 05.10^{\prime \prime} \mathrm{W}$ & open area & permanent lentic & rice paddies \\
\hline & BR08 & $26^{\circ} 53^{\prime} 26.28^{\prime \prime} \mathrm{S}, 48^{\circ} 53^{\prime} 03.90^{\prime \prime} \mathrm{W}$ & open area & temporary lentic & no vegetation \\
\hline & BR09 & $26^{\circ} 51^{\prime} 52.68^{\prime \prime} \mathrm{S}, 49^{\circ} 02^{\prime} 38.64^{\prime \prime} \mathrm{W}$ & forest edge & permanent lentic & arboreal, shrub and grass \\
\hline & BR10 & $26^{\circ} 51^{\prime} 57.66^{\prime \prime} \mathrm{S}, 49^{\circ} 02^{\prime} 32.94^{\prime \prime} \mathrm{W}$ & open area & permanent lentic & shrub and grass \\
\hline & BR11 & $26^{\circ} 52^{\prime} 00.18^{\prime \prime} \mathrm{S}, 49^{\circ} 02^{\prime} 32.46^{\prime \prime} \mathrm{W}$ & forest edge & permanent lentic & arboreal, shrub and grass \\
\hline & BR12 & $26^{\circ} 52^{\prime} 34.56^{\prime \prime} \mathrm{S}, 49^{\circ} 10^{\prime} 40.56^{\prime \prime} \mathrm{W}$ & forest edge & permanent lentic & arboreal, shrub, grass and aquatic plants \\
\hline & BR13 & $26^{\circ} 52^{\prime} 33.18^{\prime \prime} \mathrm{S}, 49^{\circ} 10^{\prime} 39.24^{\prime \prime} \mathrm{W}$ & forest edge & permanent lentic & arboreal, shrub and grass \\
\hline & BR14 & $26^{\circ} 52^{\prime} 32.70^{\prime \prime} \mathrm{S}, 49^{\circ} 10^{\prime} 42.00^{\prime \prime} \mathrm{W}$ & forest interior & permanent lentic & arboreal, shrub, grass and aquatic plants \\
\hline & BR15 & $26^{\circ} 56^{\prime} 18.61^{\prime \prime} \mathrm{S}, 49^{\circ} 17^{\prime} 28.53^{\prime \prime} \mathrm{W}$ & forest interior & permanent lotic & arboreal and shrubs \\
\hline & BR16 & $26^{\circ} 56^{\prime} 19.68^{\prime \prime} \mathrm{S}, 49^{\circ} 17^{\prime} 30.14^{\prime \prime} \mathrm{W}$ & open area & permanent lentic & shrub and grass \\
\hline \multirow[t]{13}{*}{ MGAN } & MA01 & $27^{\circ} 28^{\prime} 26.46^{\prime \prime} \mathrm{S}, 48^{\circ} 58^{\prime} 26.46^{\prime \prime} \mathrm{W}$ & open area & permanent lentic & shrub and grass \\
\hline & MA02 & $27^{\circ} 28^{\prime} 24.90^{\prime \prime} \mathrm{S}, 48^{\circ} 58^{\prime} 26.40^{\prime \prime} \mathrm{W}$ & forest edge & permanent lentic & arboreal, shrub and grass \\
\hline & MA03 & $27^{\circ} 28^{\prime} 23.64^{\prime \prime} \mathrm{S}, 48^{\circ} 58^{\prime} 26.88^{\prime \prime} \mathrm{W}$ & open area & temporary lentic & shrub and grass \\
\hline & MA04 & $27^{\circ} 28^{\prime} 24.30^{\prime \prime S}, 48^{\circ} 58^{\prime} 27.78^{\prime \prime} \mathrm{W}$ & forest interior & permanent lotic & arboreal and shrubs \\
\hline & MA05 & $27^{\circ} 28^{\prime} 19.38^{\prime \prime} \mathrm{S}, 48^{\circ} 58^{\prime} 25.98^{\prime \prime} \mathrm{W}$ & forest edge & temporary lentic & shrub and grass \\
\hline & MA06 & $27^{\circ} 28^{\prime} 12.90^{\prime \prime} \mathrm{S}, 48^{\circ} 58^{\prime} 27.24^{\prime \prime} \mathrm{W}$ & forest interior & temporary lentic & arboreal and shrubs \\
\hline & MA07 & $27^{\circ} 27^{\prime} 49.68^{\prime \prime} \mathrm{S}, 48^{\circ} 58^{\prime} 31.74^{\prime \prime} \mathrm{W}$ & forest edge & temporary lentic & arboreal, shrub, grass and taboas \\
\hline & MA08 & $27^{\circ} 27^{\prime} 60.00^{\prime \prime} \mathrm{S}, 48^{\circ} 58^{\prime} 41.22^{\prime \prime} \mathrm{W}$ & forest interior & permanent lotic & arboreal and shrubs \\
\hline & MA09 & $27^{\circ} 27^{\prime} 55.50^{\prime \prime} \mathrm{S}, 48^{\circ} 58^{\prime} 54.06^{\prime \prime} \mathrm{W}$ & forest edge & permanent lentic & arboreal and shrubs \\
\hline & MA10 & $27^{\circ} 27^{\prime} 47.52^{\prime \prime} \mathrm{S}, 48^{\circ} 58^{\prime} 46.02^{\prime \prime} \mathrm{W}$ & forest edge & permanent lentic & arboreal, shrub and grass \\
\hline & MA11 & $27^{\circ} 27^{\prime} 23.22^{\prime \prime} \mathrm{S}, 48^{\circ} 59^{\prime} 24.96^{\prime \prime} \mathrm{W}$ & forest interior & permanent lotic & arboreal and shrubs \\
\hline & MA12 & $27^{\circ} 26^{\prime} 42.24^{\prime \prime} \mathrm{S}, 48^{\circ} 58^{\prime} 54.90^{\prime \prime} \mathrm{W}$ & forest edge & permanent lotic & arboreal and shrubs \\
\hline & MA13 & $27^{\circ} 27^{\prime} 21.90^{\prime \prime} \mathrm{S}, 48^{\circ} 58^{\prime} 52.50^{\prime \prime} \mathrm{W}$ & forest edge & temporary lentic & grass between rocks \\
\hline \multirow[t]{14}{*}{ SC-370 } & $\mathrm{SCO1}$ & $28^{\circ} 00^{\prime} 38.88^{\prime \prime} \mathrm{S}, 49^{\circ} 32^{\prime} 00.36^{\prime \prime} \mathrm{W}$ & open area & permanent lentic & grass \\
\hline & $\mathrm{SCO}$ & $28^{\circ} 00^{\prime} 37.86^{\prime \prime S}, 49^{\circ} 32^{\prime} 01.38^{\prime \prime} \mathrm{W}$ & open area & temporary lentic & grass \\
\hline & $\mathrm{SCO3}$ & $28^{\circ} 00^{\prime} 36.78^{\prime \prime} \mathrm{S}, 49^{\circ} 32^{\prime} 09.54^{\prime \prime} \mathrm{W}$ & forest interior & permanent lotic & arboreal and shrubs \\
\hline & $\mathrm{SCO} 4$ & $28^{\circ} 00^{\prime} 37.86^{\prime \prime} \mathrm{S}, 49^{\circ} 32^{\prime} 10.92^{\prime \prime} \mathrm{W}$ & forest edge & permanent lentic & arboreal, shrub and grass \\
\hline & SC05 & $28^{\circ} 00^{\prime} 43.74^{\prime \prime} \mathrm{S}, 49^{\circ} 31^{\prime} 59.22^{\prime \prime} \mathrm{W}$ & forest edge & permanent lotic & arboreal and shrubs \\
\hline & $\mathrm{SCO6}$ & $28^{\circ} 02^{\prime} 27.42^{\prime \prime} \mathrm{S}, 49^{\circ} 28^{\prime} 23.28^{\prime \prime} \mathrm{W}$ & forest edge & permanent lotic & arboreal and shrubs \\
\hline & $\mathrm{SCO}$ & $28^{\circ} 02^{\prime} 23.94^{\prime \prime} \mathrm{S}, 49^{\circ} 28^{\prime} 14.82^{\prime \prime} \mathrm{W}$ & forest interior & temporary lentic & arboreal and shrubs \\
\hline & $\mathrm{SC08}$ & $28^{\circ} 02^{\prime} 23.70^{\prime \prime} \mathrm{S}, 49^{\circ} 28^{\prime} 11.64^{\prime \prime} \mathrm{W}$ & forest edge & permanent lotic & arboreal and shrubs \\
\hline & Sc09 & $28^{\circ} 02^{\prime} 54.72^{\prime \prime} \mathrm{S}, 49^{\circ} 27^{\prime} 37.38^{\prime \prime} \mathrm{W}$ & open area & temporary lentic & shrub and grass \\
\hline & $\mathrm{SC} 10$ & $28^{\circ} 02^{\prime} 57.36^{\prime \prime} \mathrm{S}, 49^{\circ} 27^{\prime} 35.04^{\prime \prime} \mathrm{W}$ & open area & temporary lentic & shrub and grass \\
\hline & SC11 & $28^{\circ} 03^{\prime} 12.90^{\prime \prime} \mathrm{S}, 49^{\circ} 25^{\prime} 49.80^{\prime \prime} \mathrm{W}$ & open area & temporary lentic & grass \\
\hline & $\mathrm{SC} 12$ & $28^{\circ} 03^{\prime} 32.52^{\prime \prime} \mathrm{S}, 49^{\circ} 25^{\prime} 27.90^{\prime \prime} \mathrm{W}$ & open area & permanent lentic & grass \\
\hline & $\mathrm{SC} 13$ & $28^{\circ} 03^{\prime} 24.78^{\prime \prime} \mathrm{S}, 49^{\circ} 25^{\prime} 28.44^{\prime \prime} \mathrm{W}$ & open area & permanent lentic & shrub and grass \\
\hline & $\mathrm{SC} 14$ & $28^{\circ} 03^{\prime} 26.10^{\prime \prime} \mathrm{S}, 49^{\circ} 25^{\prime} 23.82^{\prime \prime} \mathrm{W}$ & open area & temporary lentic & shrub and grass \\
\hline \multirow[t]{13}{*}{ BR-116 } & FZO1 & $25^{\circ} 36^{\prime} 04.35^{\prime \prime} \mathrm{S}, 49^{\circ} 19^{\prime} 13.12^{\prime \prime} \mathrm{W}$ & forest edge & permanent lentic & arboreal, shrub and grass \\
\hline & $\mathrm{FZO2}$ & $25^{\circ} 35^{\prime} 53.03^{\prime \prime} \mathrm{S}, 49^{\circ} 18^{\prime} 36.68^{\prime \prime} \mathrm{W}$ & open area & temporary lentic & shrub and grass \\
\hline & FZO3 & $25^{\circ} 35^{\prime} 55.34^{\prime \prime} \mathrm{S}, 49^{\circ} 18^{\prime} 36.61^{\prime \prime} \mathrm{W}$ & forest interior & permanent lotic & arboreal and shrubs \\
\hline & FZO4 & $25^{\circ} 37^{\prime} 03.31^{\prime \prime} \mathrm{S}, 49^{\circ} 18^{\prime} 59.51^{\prime \prime} \mathrm{W}$ & open area & permanent lentic & grass and aquatic plants \\
\hline & FZ05 & $25^{\circ} 37^{\prime} 10.24^{\prime \prime} \mathrm{S}, 49^{\circ} 18^{\prime} 57.33^{\prime \prime} \mathrm{W}$ & open area & permanent lentic & grass and aquatic plants \\
\hline & FZO6 & $25^{\circ} 36^{\prime} 32.88^{\prime \prime} \mathrm{S}, 49^{\circ} 19^{\prime} 33.48^{\prime \prime} \mathrm{W}$ & forest edge & permanent lentic & arboreal, shrub and grass \\
\hline & $\mathrm{FZO7}$ & $25^{\circ} 37^{\prime} 00.20^{\prime \prime} \mathrm{S}, 49^{\circ} 19^{\prime} 08.01^{\prime \prime} \mathrm{W}$ & forest edge & permanent lentic & arboreal, shrub and grass \\
\hline & FZO8 & $25^{\circ} 43^{\prime} 06.06^{\prime \prime} \mathrm{S}, 49^{\circ} 19^{\prime} 03.63^{\prime \prime} \mathrm{W}$ & open area & permanent lentic & shrub and grass \\
\hline & FZO9 & $25^{\circ} 43^{\prime} 10.00^{\prime \prime} \mathrm{S}, 49^{\circ} 19^{\prime} 00.31^{\prime \prime} \mathrm{W}$ & forest interior & permanent lotic & arboreal and shrubs \\
\hline & $\mathrm{FZ10}$ & $25^{\circ} 44^{\prime} 03.62^{\prime \prime} \mathrm{S}, 49^{\circ} 19^{\prime} 00.47^{\prime \prime} \mathrm{W}$ & open area & permanent lentic & shrub and grass \\
\hline & FZ11 & $25^{\circ} 44^{\prime} 49.66^{\prime \prime S}, 49^{\circ} 19^{\prime} 07.01^{\prime \prime} \mathrm{W}$ & open area & permanent lentic & shrub e gramínea \\
\hline & $\mathrm{FZ12}$ & $25^{\circ} 44^{\prime} 48.29^{\prime \prime} \mathrm{S}, 49^{\circ} 19^{\prime} 13.45^{\prime \prime} \mathrm{W}$ & forest edge & permanent lentic & arboreal, shrub and grass \\
\hline & FZ13 & $25^{\circ} 44^{\prime} 53.61^{\prime \prime} \mathrm{S}, 49^{\circ} 19^{\prime} 23.05^{\prime \prime} \mathrm{W}$ & forest interior & permanent lotic & arboreal, shrub and taquaral \\
\hline
\end{tabular}




\section{APPENDIX 2}

Sampling effort in each studied locality: BR-470 - BR-470 highway between Ilhota and Indaial municipalities, Santa Catarina state; MGAN - between Angelina and Major Gercino municipalities, Santa Catarina state; SC-370 - SC-370 highway in Urubici municipality, Santa Catarina state; and BR-116 - BR-116 highway between Curitiba and Mandirituba municipalities, Paraná state.

\begin{tabular}{cccc}
\hline Locality & Data & Number of campaings & Sampling effort \\
\hline BR-470 & 2010 & 4 & 80 hours \\
MGAN & $2010-2011$ & 4 & 80 hours \\
SC-370 & $2010-2011$ & 3 & 60 hours \\
BR-116 & $2012-2013$ & 8 & 160 hours \\
\hline
\end{tabular}

\section{APPENDIX 3}

Voucher numbers of collected anuran specimens from MGAN, BR-470, BR-116 and SC-370.

Adenomera araucaria: CZFURB 14683, 22704, 22902; Adenomera engelsi: CZFURB 14217; Adenomera nana: CZFURB 14410, 14416, 14417, 22660, 22661, 22662, 22776, 22777, 22778, 22780; Boana albomarginata: CZFURB 22789; Boana albopunctata: CZFURB 22291; Boana bischoffi: CZFURB 14214, 14215, 14216, 14224, 14225, 14226, 14229, 14230, 14235, 14236, 14292, 14293, 14297, 22791; Boana faber: CZFURB 14227, 14239, 14301, 22793; Bokermannohyla hylax: CZFURB 14219, 14228, 14241, 14242, 14296; Cycloramphus bolitoglossus: CZFURB 22310; Dendropsophus microps: CZFURB 14377, 14693; Dendropsophus minutus: CZFURB 14376, 14681, 14692; Dendropsophus nahdereri: CZFURB 14686; Dendropsophus werneri: CZFURB 14294, 14694; Haddadus binotatus: CZFURB 14378, 22782, 22783; Hylodes perplicatus: CZFURB 14531, 14532, 14533, 22781, 22786; Ischnocnema henselii: CZFURB 14380, 14680, 22389, 22787; Ischnocnema manezinho: CZFURB 14231; Leptodactylus latrans: CZFURB 14145, 14237, 14374, 14381, 14382, 14414, 14415, 22650, 22651, 22652, 22653, 22654, 22655, 22656, 22779, 22785; Leptodactylus notoaktites: CZFURB 14147; Leptodactylus plaumanni: CZFURB 14670, 14671, 14672, 14674; Lithobates catesbeianus: CZFURB 14669, 22657; Phyllomedusa distincta: CZFURB 14295, 14684, 22792; Physalaemus aff. gracilis: CZFURB 14673, 14675, 14676, 14678, 22379; Physalaemus cuvieri: CZFURB 14383, 14418, 14677, 14679, 22804; Physalaemus lateristriga: CZFURB 14149, 14687, 22658, 22659, 22773, 22803; Physalaemus nanus: CZFURB 14233, 14234, 14238, 14379, 22784, 22967; Proceratophrys boiei: CZFURB 22465, 22801; Rhinella abei: CZFURB 14143, 14144, 14146, 14148, 14150, 14212, 14220, 14240, 14375, 14384, 22272, 22663, 22664, 22665, 22666, 22667, 22668, 22774, 22775, 22802, 22978; Rhinella icterica: CZFURB 14211, 14213, 14221, 14222, 14223, 14243, 14298, 14299, 14300, 14668; Scinax fuscovarius: CZFURB 14685; Scinax imbegue: CZFURB 14690, 22790; Scinax perereca: CZFURB 14218, 14688, 14689; Scinax rizibilis: CZFURB 14232, 14695; Scinax tymbamirim: CZFURB 14372, 14373, 14691; Sphaenorhynchus surdus: CZFURB 14682, 22277; Vitreorana uranoscopa: CZFURB 14696, 14697.

\section{APPENDIX 4}

Species contribution of Beta Diversity (SCBD) of anuran species of four sampled taxocenoses: BR-470 - BR-470 highway between Ilhota and Indaial municipalities, Santa Catarina state; MGAN - between Angelina and Major Gercino municipalities, Santa Catarina state; SC-370 - SC-370 highway in Urubici municipality, Santa Catarina state; and BR-116 - BR-116 highway between Curitiba and Mandirituba municipalities, Paraná state.

\begin{tabular}{ll}
\hline \multicolumn{1}{c}{ Species } & SCBD \\
\hline Dendropsophus sanborni & 0.062 \\
Dendropsophus nahdereri & 0.061 \\
Physalaemus aff. gracilis & 0.054 \\
Adenomera nana & 0.049 \\
Adenomera araucaria & 0.048 \\
Scinax imbegue & 0.047 \\
Scinax tymbamirim & 0.047 \\
Dendropsophus werneri & 0.046 \\
Sphaenorhynchus caramaschii & 0.046 \\
Phyllomedusa distincta & 0.040 \\
Lithobates catesbeianus & 0.037 \\
Boana guentheri & 0.035 \\
Boana albopunctata & 0.034 \\
Sphaenorhynchus surdus & 0.032 \\
Physalaemus nanus & 0.031 \\
\hline
\end{tabular}

\begin{tabular}{ll}
\hline \multicolumn{1}{c}{ Species } & SCBD \\
\hline Aplastodiscus albosignatus & 0.028 \\
Dendropsophus microps & 0.027 \\
Physalaemus lateristriga & 0.021 \\
Scinax fuscovarius & 0.021 \\
Dendropsophus minutus & 0.021 \\
Physalaemus cuvieri & 0.019 \\
Hylodes perplicatus & 0.018 \\
Aplastodiscus perviridis & 0.017 \\
Proceratophrys brauni & 0.017 \\
Fritiziana mitus & 0.017 \\
Rhinella abei & 0.015 \\
Leptodactylus plaumanii & 0.013 \\
Leptodactylus notoaktites & 0.013 \\
Boana joaquini & 0.011 \\
Rhinella icterica & 0.011
\end{tabular}

\begin{tabular}{ll}
\hline \multicolumn{1}{c}{ Species } & SCBD \\
\hline Boana prasina & 0.011 \\
Scinax perereca & 0.010 \\
Bokermannohyla circumdata & 0.006 \\
Ischnocnema henselii & 0.006 \\
Proceratophrys boiei & 0.006 \\
Boana bischoffi & 0.004 \\
Leptodactylus latrans & 0.004 \\
Boana faber & 0.003 \\
Ololygon rizibilis & 0.002 \\
Cycloramphus bolitoglossus & 0.002 \\
Odontophrynus americanus & 0.002 \\
Adenomera engelsi & 0.001 \\
Bokermannohyla hylax & 0.001 \\
Haddadus binotatus & 0.001 \\
Ischnocnema manezinho & 0.001 \\
\hline
\end{tabular}

